\title{
Chemical defense against predators and bacterial fouling in the Mediterranean sponges Axinella polypoides and $A$. verrucosa
}

\author{
Markus Haber ${ }^{1,2}$, Marianna Carbone ${ }^{2}$, Ernesto Mollo $^{2}$, Margherita Gavagnin ${ }^{2}$, \\ Micha Ilan ${ }^{1, *}$
}

${ }^{1}$ Department of Zoology, Tel Aviv University, Tel Aviv, 69978, Israel
${ }^{2}$ Istituto di Chimica Biomolecolare, CNR, Pozzuoli-Napoli, 80078, Italy

\begin{abstract}
The diverse natural products found within sponges mediate many of their ecological interactions, including predator feeding deterrence and defense against fouling. Pyrrole-imidazole compounds, often involved in such ecological interactions, are exclusively found in marine sponges, mainly from the genera Axinella and Agelas. Employing field and laboratory assays, we studied the chemical defense of 2 co-occurring Mediterranean sponges, Axinella polypoides and A. verrucosa, collected from the Gulf of Naples, Italy, against microbial fouling, as well as their feeding deterrence against the generalist shrimp Palaemon elegans. These assays revealed no activity in the extracts of A. polypoides, while the $n$-butanol part of the A. verrucosa extract showed activity in all assays at natural concentrations. This fraction of the extract contains the bromopyrrole hymenidin, and our assays revealed antibacterial and feeding deterrence activity for this pure compound. ${ }^{1} \mathrm{H}$ nuclear magnetic resonance quantification confirmed the presence of hymenidin and debromo-carteramine $\mathrm{A}$, another previously isolated antibacterial compound, at ecologically relevant concentrations in the $n$-butanol part of the A. verrucosa extract. Our results indicate different antimicrobial and feeding deterrence defense strategies in the 2 examined sympatric sponge species, and multiple defensive roles of hymenidin in the defense of $A$. verrucosa, similar to those of other bromopyrroles isolated from taxonomically related Caribbean sponges.
\end{abstract}

KEY WORDS: Bromopyrroles $\cdot$ Antifouling $\cdot$ Feeding deterrence $\cdot$ Chemical ecology $\cdot$ Porifera

Resale or republication not permitted without written consent of the publisher

\section{INTRODUCTION}

Filter-feeding sponges, which are among the oldest metazoans, are an important part of the marine benthic community. These soft-bodied, sessile organisms are well known for their plethora of diverse secondary metabolites (Blunt et al. 2009 and references therein). Many of these metabolites are involved in ecological interactions such as defense against bacterial, fungal, and viral pathogens (Kelman et al. 2001, Mayer \& Hamann 2005), as well as in competition for space (Engel \& Pawlik 2000, Pawlik et al. 2007a). The 2 most commonly studied and presumed ecological roles for sponge secondary metabolites are those of antifouling defense (e.g. Kubanek et al. 2002, Tsoukatou et al. 2002) and predator deterrence (e.g. Pawlik et al. 1995, Burns et al. 2003, Furrow et al. 2003, Sokolover \& Ilan 2007).

Fouling can be considered detrimental to sponges, as epibionts may block the sponge orifices, thus preventing effective filter feeding and leading to starvation and possibly death of the fouled sponge (Wahl 1989). It is therefore not surprising that many sponges maintain an epibiont-free surface. Some sponges prevent blocking of their filter apparatus by physical mechanisms such as regular tissue sloughing (Barthel \& Wolfrath 1989, De Goeij et al. 2009), while other species rely on chemical defense against fouling as shown by field and 
laboratory experiments (e.g. Tsoukatou et al. 2002, Dobretsov et al. 2005a,b, Lee et al. 2007, Qian et al. 2010). One of the first steps in the fouling process is bacterial settlement and the establishment of a biofilm, which can influence the later settlement of macrofouling organisms such as barnacles and polychaetes (Sjögren et al. 2004, Lau et al. 2005, Lee et al. 2007). Modulation or prevention of bacterial settlement is therefore a likely target for the sponge's antifouling compounds (Kubanek et al. 2002, Kelly et al. 2003, Lee et al. 2007). Organic extracts and pure compounds from several sponges have been shown to inhibit settlement and growth of environmental bacteria (e.g. Amade et al. 1987, Newbold et al. 1999, Kelman et al. 2001, Kelly et al. 2003).

The involvement of sponge metabolites in feeding deterrence has often been assumed, because sponges are soft-bodied animals that are unable to move or hide once settled. Most sponges have high nutritional values, eliminating the possibility of predator avoidance due to low nutritional value (Kubanek et al. 2002). While there is evidence for feeding deterrence based solely on physical defense by spicules or sponge skeleton elements in some sponges (Burns \& Ilan 2003, Hill et al. 2005, Ferguson \& Davis 2008), the synergistic effects of physical and chemical defenses (Jones et al. 2005) along with feeding deterrence by means of organic extracts and purified compounds have been reported more often than physical defense alone for sponges from diverse geographical regions (e.g. Pawlik et al. 1995, Burns et al. 2003, Sokolover \& Ilan 2007). As not all sponges are chemically defended, predation is considered a key factor in the distribution of sponges, limiting most undefended sponges to cryptic habitats with reduced susceptibility to predation (Wright et al. 1997, Pawlik et al. 2007b). Some undefended sponge species might persist in open habitats by investing more energy into growth, reproduction, and wound-healing, rather than investing resources in energetically costly defensive metabolites (Pawlik 1993), and thus are able to tolerate and cope with predation (Walters \& Pawlik 2005, Pawlik et al. 2008, Leong \& Pawlik 2010).

In the present study, we investigated the chemical defense of 2 sympatric sponges, Axinella polypoides (Schmidt 1862) and A. verrucosa (Elsper 1794) (collected from the Gulf of Naples, Italy), which co-occur on the rock reefs of the Mediterranean Sea, against microbial fouling and in deterring feeding by a generalist predator. Bromopyrrole compounds have previously been isolated from A. verrucosa (Cimino et al. 1975, Aiello et al. 2006, Haber et al. 2010) and other species of Axinella and the related genus Agelas (Braekman et al. 1992, Chanas et al. 1997, Wilson et al. 1999, Assmann et al. 2001a, Richelle-Maurer et al. 2003), but ap- pear to be absent from A. polypoides (Cimino et al. 1975). Several bromopyrroles have been shown to play multiple defensive roles in Caribbean sponges, acting as defense agents in competition for space (RichelleMaurer et al. 2003), feeding deterrence (Chanas et al. 1997, Wilson et al. 1999), and against microbial fouling (Kelly et al. 2003). We therefore hypothesized that A. verrucosa possesses chemical defenses mediated by its bromopyrroles. To test this hypothesis, we compared the chemical defenses of $A$. verrucosa to those of the sympatric $A$. polypoides, which lacks this type of compound. We first compared extracts of the 2 Mediterranean Axinella sponge species for their ability to inhibit both bacterial settlement in the field, and the growth of a panel of environmental and laboratory bacteria in laboratory assays. We then assessed the ability of Axinella spp. extracts to deter the generalist shrimp Palaemon elegans (Rathke 1837) from feeding. Finally, we addressed the ecological role of the pure bromopyrrole compound hymenidin, recently isolated from $A$. verrucosa (also collected from the Gulf of Naples) by bioassay-guided isolation against an environmental bacterium (Haber et al. 2010). To determine the ecological relevance of the pure compound, we tested it in both the antibacterial growth assay and in the feeding deterrence experiment and compared the active concentrations to the natural concentrations as measured by ${ }^{1} \mathrm{H}$ nuclear magnetic resonance (NMR).

\section{MATERIALS AND METHODS}

Sponge collection and extraction. Axinella polypoides and A. verrucosa were collected in June 2008 by SCUBA diving in front of Nisida in the Bay of Naples, Italy, from depths of 16 to $22 \mathrm{~m}$. Parts of several individual sponges were cut with a sterile scalpel blade and placed separately in plastic bags, allowing recuperation and regeneration of the remaining sponge individuals. The biological material was immediately transferred in a cooler to the laboratory, where it was cleansed of macro-epibionts, rinsed once, and kept at $-20^{\circ} \mathrm{C}$ until extraction. The frozen material, a pool of several individuals, was cut into pieces of about $1 \mathrm{~cm}^{3}$. The total volume was determined by solvent displacement, and the material was extracted exhaustively (4 times) with acetone (500 $\mathrm{ml}$ total volume) under grinding and sonication (10 $\mathrm{min}$ ) until the resulting extract was colorless. Extracts were combined after filtration, and the organic solvent was removed under reduced pressure using a rotorvapor and gentle heating in the water bath $\left(<30^{\circ} \mathrm{C}\right)$. The residual water was partitioned against ethylether $\left(\mathrm{Et}_{2} \mathrm{O}\right)$ until the resulting $\mathrm{Et}_{2} \mathrm{O}$ phase was colorless (4 times) and subsequently once with $n$-butanol. The combined $\mathrm{Et}_{2} \mathrm{O}$ phases and 
the $n$-butanol phase were dried under reduced pressure to give 2 extract partitions for each sponge species. Partitions were transferred to glass vials with solvents, dried, and stored at $-20^{\circ} \mathrm{C}$ until used in assays. Extract weights and resulting natural concentrations are given in Table 1.

Bacterial settlement field assay. The bacterial settlement field assay was adapted from similar methods described by Henrikson \& Pawlik (1995), Harder et al. (2004), Dobretsov et al. (2005a,b), and Lee et al. (2007). Extracts were re-dissolved by gentle sonication using methanol for $n$-butanol and $\mathrm{Et}_{2} \mathrm{O}$ for $\mathrm{Et}_{2} \mathrm{O}$ partitions to give 10-fold natural concentrations. Aliquots $(4.4 \mathrm{ml})$ of each partition were transferred to $50 \mathrm{ml}$ Falcon tubes, diluted to natural concentration with an autoclaved $5 \%$ agar solution (weight/volume), which had been cooled to $50^{\circ} \mathrm{C}$. Aliquots $(4 \mathrm{ml})$ of the thoroughly mixed solutions were poured into sterile Petri dishes $(35 \mathrm{~mm}$ diameter) in a laminar flow cabinet. Plates were left open for $1 \mathrm{~h}$ to allow solidification and evaporation of remaining solvents. Controls were prepared in the same manner with solvents only. After solidification, plates were attached to $2 \mathrm{~m}$ nylon lines, covered with lids, wrapped in Parafilm ${ }^{\circledR}$, and stored for $1 \mathrm{~d}$ at $4^{\circ} \mathrm{C}$ to allow further compound diffusion. Lids were removed directly before employing the setup in the sea. A float was attached to each line, and each line was connected to a weight on the sand floor at a depth of $18.5 \mathrm{~m}$, close to a rock formation with Axinella verrucosa and A. polypoides in front of the island of Nisida, where the sponge samples had previously been collected. Lines were spread out in 2 rows with each extract partition and control in each row. Order within rows was random, and each line was about $80 \mathrm{~cm}$ distant from the next. Lines were retrieved after $24 \mathrm{~h}$ in a sterile manner and placed underwater in a bag. The closed bags were placed immediately into ice water in a cooler and kept there until arrival at the laboratory, where plates were covered with their lids while still under water from the field site in their bags and using gloves.

Table 1. Axinella polypoides and A. verrucosa. Extract partition weights and resulting natural concentrations. nd: not determined

\begin{tabular}{|lcc|}
\hline & A. polypoides & A. verrucosa \\
\hline Partition weight (mg) & & \\
Et $_{2} \mathrm{O}$ partition & 340 & 369 \\
$n$-butanol partition & 210 & 838 \\
Natural tissue concentration $\mathbf{( \mathbf { m g ~ m } ^ { \mathbf { 1 } } \text { ) }}$ & \\
Et $\mathrm{g}_{2} \mathrm{O}$ partition & 6.2 & 6.7 \\
$n$-butanol partition & 3.8 & 15.2 \\
Hymenidin & $\mathrm{nd}$ & 3.8 \\
Debromo-carteramine A & $\mathrm{nd}$ & 1.0 \\
\hline
\end{tabular}

Excess water was removed immediately before plates were processed for scoring the assay. Bacterial settlement on plates was scored in 2 ways: direct bacterial counts using 4',6-diamidino-2-phenylindole-dihydrochloride (DAPI) staining and counts of colony-forming units (from here on referred to as DAPI and CFU counts). Three plates from each extract partition and control were assigned randomly to each analysis.

Each plate designated for CFU counts was swabbed with a sterile cotton swab making sure every part of the plate had been swabbed several times. The swab was immersed in $4 \mathrm{ml}$ of $0.22 \mu \mathrm{m}$ filtered seawater, vortexed for $1 \mathrm{~min}$, and removed, giving the initial bacteria suspension. A total of $50 \mu$ l of a 10 -fold dilution with $0.22 \mu \mathrm{m}$ filter sterilized seawater were plated out on a marine agar plate (37.4 g Marine Broth 2166, $18 \mathrm{~g}$ agar, $1 \mathrm{l}$ distilled water) until the plate was dry. Colonies were counted after $24 \mathrm{~h}$ of incubation at room temperature (around $25^{\circ} \mathrm{C}$ ). The number of CFUs $\mathrm{mm}^{-2}$ of the original assay Petri dish was calculated for comparison to the DAPI counts.

Plates for the DAPI counts were fixed by addition of $0.5 \mathrm{ml} 4 \%$ para-formaldehyde solution, wrapped in Parafilm ${ }^{\circledR}$, and stored in the dark at $4^{\circ} \mathrm{C}$ until counts were conducted. A total of $10 \mu \mathrm{l}$ of a freshly prepared $20 \mu \mathrm{g} \mathrm{ml}^{-1}$ DAPI solution were applied to a cover slide. The cover slide was gently pressed on the assay plate after excess formaldehyde solution had been removed and left in the dark for at least $10 \mathrm{~min}$ at room temperature. The plate was then observed under an epifluorescence microscope under a total magnification of $1000 \times$ using immersion oil. Ten randomly chosen grids consisting of 20 fields $\left(12 \times 12 \mu^{2}\right)$ were counted per plate. When low numbers of bacteria were present, counts were continued until at least 150 bacteria plate $^{-1}$ had been counted in order to obtain statistically relevant numbers. The mean number of bacteria $\mathrm{mm}^{-2}$ was calculated for each plate and used for statistical analysis.

For statistical analysis, data were log-transformed to normalize variation following Dobretsov et al. (2005a,b). Normality of data was ascertained by KolmogorovSmirnov and Shapiro-Wilk tests. Significances of differences between partitions and controls were calculated by 1-way analysis of variance (ANOVA) followed by Tukey's post hoc tests with $\mathrm{p}<0.05$ considered significant using the SPSS software version 15.0.1. The 2 scoring methods were analyzed separately.

Isolation and characterization of environmental bacteria for antibacterial assays. Bacteria were isolated from water and sediment samples collected close to the sponges Axinella polypoides and A. verrucosa on a $30 \mathrm{~m}$ deep reef at Sdot Yam, Israel (ESY strains), and from a reef at $20 \mathrm{~m}$ near Naharriya, Israel (NB strains). Samples were plated on marine agar 2216 and 
Luria-Bertani (LB) agar plates (10 g tryptone, $5 \mathrm{~g}$ yeast extract, $5 \mathrm{~g} \mathrm{NaCl}, 18$ agar, $1 \mathrm{l}$ distilled water). After $6 \mathrm{~d}$ of incubation at room temperature, colonies with unique morphology were transferred to new plates until pure cultures were obtained. Pure stocks were secured by adding $1 \mathrm{ml}$ of a liquid culture to $500 \mu \mathrm{l}$ $50 \%$ glycerol and freezing the stock at $-80^{\circ} \mathrm{C}$.

Bacteria were characterized by sequencing part of the $16 \mathrm{~S}$ rDNA using the 63f primer. Part of a colony was transferred to $30 \mu \mathrm{l}$ Tris-EDTA buffer (10 mM TrisHCl, 1 mM EDTA, pH 8.0) buffer in a 1.5 ml Eppendorf tube, and cells were lysed by 3 cycles of freezing at $-80^{\circ} \mathrm{C}$ for $1 \mathrm{~h}$ followed by heating to $95^{\circ} \mathrm{C}$ for $10 \mathrm{~min}$. A total of $1 \mu \mathrm{l}$ of this mix was added to a $0.2 \mathrm{ml}$ tube containing $2.5 \mu \mathrm{l} 10 \times$ PCR buffer, $2.0 \mu \mathrm{l} 2.5 \mathrm{mM}$ of each dNTP, $0.25 \mu \mathrm{l}$ of each $100 \mathrm{mM}$ primer (63f and 1387r),

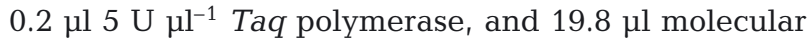
grade water. The PCR protocol consisted of 3 min at $94^{\circ} \mathrm{C}, 30$ cycles of $1 \mathrm{~min}$ at $94^{\circ} \mathrm{C}, 1 \mathrm{~min}, 20 \mathrm{~s}$ at $54^{\circ} \mathrm{C}, 2$ min at grade $72^{\circ} \mathrm{C}$; followed by 5 min at $72^{\circ} \mathrm{C}$. The PCR products were cleaned with the Nucleospin kit (Macherey-Nagel) following the manufacturer's instructions and sequenced at the Sequencing Unit of the Inter-Departmental Research Facility Unit of Tel Aviv University using the BigDye ${ }^{\circledR}$ Terminator Cycle Sequencing Kit (Applied Biosystems) and an ABI PRISM 3100 Genetic Analyzer. Obtained raw sequences were manually edited and blasted using the blastn algorithm (Altschul et al. 1990, http://blast.ncbi.nlm. nih.gov) to determine the bacterial genus. The sequences were uploaded to GenBank, and accession numbers are given in Table 2 .

Antibacterial activity assay. Disc diffusion assays were performed with 4 laboratory (2 Gram-positive and 2 Gram-negative) and 6 environmental bacteria (3 Gram-positive and 3 Gram-negative). LB or marine agar plates were seeded with $200 \mu$ l of a well-grown overnight (late log) culture of bacteria. A total of $20 \mu \mathrm{l}$ of $25 \mathrm{mg} \mathrm{ml}^{-1}$ extract partitions with their respective solvent, methanol for $n$-butanol and chloroform for $\mathrm{Et}_{2} \mathrm{O}$ partitions, were applied to blank paper discs resulting in $500 \mu \mathrm{g} \operatorname{disc}^{-1}$. After evaporation of solvents, the paper discs were gently pressed on the agar surface of the seeded plates. Plates were covered and incubated at $30^{\circ} \mathrm{C}$ for $48 \mathrm{~h}$. Inhibition zones were observed as clear zones without growth around the paper discs. Solvent controls prepared in the same manner were always performed in parallel and were always negative. The assay was performed in triplicate.

Minimal inhibitory concentrations against susceptible bacteria were performed as previously described (Kelman et al. 2001) by determining the smallest amount of extract needed to inhibit growth of a test bacterium. Overnight liquid bacterial cultures were adjusted to an optical density (OD) of 0.04 measured at $620 \mathrm{~nm}$ using a Turner SP-830 spectrophotometer and were afterwards diluted 1:100. A volume of $100 \mu \mathrm{l}$ were added to a 96-well plate filled with $100 \mu$ liquid LB medium, dimethyl sulfoxide (DMSO, final concentration $0.5 \%, \mathrm{v} / \mathrm{v}$ ) and a series of extract concentrations (ranging from 0.001 to $1 \mathrm{mg} \mathrm{ml}^{-1}$ ) and a solvent control. Initial OD was measured on a GENESIS workstation 200 (Tecan) using SPECTRAFluor Plus (Tecan) after $5 \mathrm{~s}$ of shaking and $2 \mathrm{~s}$ of settling at $620 \mathrm{~nm}$. Plates were incubated at $30^{\circ} \mathrm{C}$ with continuous shaking (100 rpm). OD measurement was repeated after 24,48, and 72 h. Each concentration and control was assayed in triplicate.

The minimal inhibitory concentration of hymenidin previously purified from the $n$-butanol partition of Axinella verrucosa collected at the Gulf of Naples (see Haber et al. 2010) was determined in the same manner.

Feeding deterrence assay. The feeding deterrence activity of sponge extract partitions and hymenidin was tested against the shrimp Palaemon elegans. This generalist predator is widely distributed and occurs along the European coast of the Atlantic, the North and

Table 2. Axinella polypoides and A. verrucosa. Antibacterial activity and minimal inhibitory concentrations (in $\mu \mathrm{g} \mathrm{ml} \mathrm{m}^{-1}$ ) of extract partitions and hymenidin. GenBank accession numbers are given for environmental bacteria. BE: $n$-butanol extract partition; EE: $\mathrm{Et}_{2} \mathrm{O}$ extract partition; -: no activity in the disc diffusion assay; nd: not determined

\begin{tabular}{|c|c|c|c|c|c|c|c|}
\hline \multirow[t]{2}{*}{ Species/strain } & \multirow[t]{2}{*}{ Gram type } & \multirow{2}{*}{$\begin{array}{c}\text { GenBank } \\
\text { accession no. }\end{array}$} & \multicolumn{2}{|c|}{ A. polypoides } & \multicolumn{3}{|c|}{ A. verrucosa } \\
\hline & & & $\mathrm{BE}$ & $\mathrm{EE}$ & $\mathrm{BE}$ & $\mathrm{EE}$ & Hymenidin \\
\hline Escherichia coli GM1655 & Negative & & - & - & 31 & - & 125 \\
\hline Pseudomonas aerigunosa PAO1 & Negative & & - & - & - & - & nd \\
\hline Pseudomonas sp. NB86 & Negative & GU479630 & - & - & - & - & nd \\
\hline Vibrio sp. ESY12 & Negative & GU479628 & - & - & - & - & nd \\
\hline Sulfitobacter sp. ESY17 & Negative & GU479629 & - & - & - & - & nd \\
\hline Staphylococcus aureus & Positive & & - & - & 31 & - & 31 \\
\hline Bacillus subtilis & Positive & & - & - & 16 & 125 & 31 \\
\hline Lysinibacillus sp. ESY09 & Positive & GU059941 & - & - & 31 & - & 31 \\
\hline Sporosarcina sp. NB90 & Positive & GU479626 & - & - & 16 & 63 & 16 \\
\hline Kocuria sp. ESY10 & Positive & GU479627 & - & - & 8 & 31 & 16 \\
\hline
\end{tabular}


Baltic Seas, as well as in the Mediterranean Sea (Janas et al. 2004). Assays were performed as described by Mollo et al. (2008), using food pellets containing extract partitions at natural volumetric concentrations and hymenidin at final concentrations of 1,3 , and $5 \mathrm{mg}$ $\mathrm{ml}^{-1}$. Food pellets consisted of $50 \mathrm{mg}$ ground lyophilized squid mantle, $30 \mathrm{mg}$ alginate, and $30 \mathrm{mg}$ purified sea sand (granular size 0.1 to $0.3 \mathrm{~mm}$ ). Extract partitions dissolved in $0.5 \mathrm{ml}$ acetone were added to the mix, and the solvent was evaporated. Distilled water and a drop of red food color (E110 and E124) were added to give a final volume of $1 \mathrm{ml}$. The mixed paste was exuded with a syringe into a $0.25 \mathrm{M} \mathrm{CaCl}_{2}$ solution and allowed to harden for $2 \mathrm{~min}$. After a brief rinse, the strip was cut into $10 \mathrm{~mm}$ strips. Strips with solvent only were prepared as controls. Shrimps were collected along the coast of Pozzuoli, Italy, and habituated to the control food in a 501 aquarium for $1 \mathrm{wk}$ prior to the experiments. Ten randomly chosen shrimps were assayed for each treatment (extract, compound concentration, and control). Controls and treatments were carried out in parallel. Shrimps were placed individually into $500 \mathrm{ml}$ plastic beakers filled with $300 \mathrm{ml}$ seawater. A single food strip was given to each shrimp. The almost transparent exoskeleton of the shrimps enabled easy detection of the occurrence of the red food in the gastric mill and the stomach of the shrimps. The presence of a red spot in the stomach after $30 \mathrm{~min}$ was considered as acceptance of food, while the absence of the spot was considered a rejection response. Statistical analysis between treatments and controls was performed using Fisher's exact test.

${ }^{1} \mathbf{H}$ NMR quantification of hymenidin and debromocarteramine A. Both compounds, which were previously isolated from the $n$-butanol partition of Axinella verrucosa (collected at Massa Lubrense, Gulf of Naples) and had inhibited the growth of an environmental bacterium (Haber et al. 2010), were quantified by ${ }^{1} \mathrm{H}$ NMR spectroscopy in the $n$-butanol partition of A. verrucosa collected for the present study and in the original one used for their isolation. The ${ }^{1} \mathrm{H}$ NMR spectra were acquired in $\mathrm{CD}_{3} \mathrm{OD}$ on a Bruker DRX 600 $\mathrm{MHz}$ and calibrated using the solvent impurity $\mathrm{CH}_{3} \mathrm{OD}$ at $\delta$ 3.45. As an internal standard, $1 \mathrm{mg}$ of methylparaben was used, and the doublet at $\delta 7.92$ resulting from 2 protons was used as reference for integration. The doublet at $\delta 6.33$ of hymenidin, and the singlet at $\delta$ 5.79 of debromo-carteramine $\mathrm{A}$, both resulting from a single proton of the respective compound, were used to quantify the compounds following the formula given by Fontana et al. (1992). Natural concentrations were calculated by multiplying the result with the factor of natural concentration of the $n$-butanol partition divided by the sample weight used in the quantification.

\section{RESULTS}

\section{Bacterial settlement in the field}

Both scoring methods used to assess bacterial settlement were in agreement with each other. In both cases, the 1-way ANOVA showed significant differences between treatments (CFU method: $F=18.624$, $\mathrm{p}<0.001$; DAPI method: $F=7.063, \mathrm{p}=0.003)$, and only plates which contained the $n$-butanol partition of the Axinella verrucosa extract significantly inhibited bacterial settlement compared to control plates (Tukey's post hoc tests, $\mathrm{p}<0.05$; Fig. 1). As could be expected, bacterial numbers of the DAPI counts were 1 to 2 orders of magnitude higher than CFU counts.

\section{Antibacterial activity}

The 2 sponge species differed in their antibacterial activity. Neither of the 2 partitions of the Axinella polypoides extract showed any activity against the tested bacteria. In contrast, the $n$-butanol part of the $A$. verrucosa extract consistently inhibited all tested Gram-positive bacteria and the Gram-negative Escherichia coli strain GM1655, and its $\mathrm{Et}_{2} \mathrm{O}$ partition inhibited 3 Gram-positive bacteria. Differences in the disc diffusion assays between the replicates of inhibited bacteria were low (maximal $1 \mathrm{~mm}$ ). Hymenidin, the main compound of the $A$. verrucosa $n$-butanol partition, inhibited the same bacteria as the $n$-butanol partition, but minimal inhibitory concentrations were the same or higher, indicating less activity than found in the partition from which it had been isolated (Table 2).

\section{Feeding deterrence}

Feeding deterrence was assayed against Palaemon elegans, a generalist predator. Only the $n$-butanol partition of the Axinella verrucosa extract significantly deterred this shrimp from feeding at natural volumetric concentration, whereas its $\mathrm{Et}_{2} \mathrm{O}$ partition and both partitions from the $A$. polypoides extract did not inhibit feeding (Fig. 2). The pure compound hymenidin was a significant deterrent at concentrations of 3 and $5 \mathrm{mg}$ $\mathrm{ml}^{-1}$, but not at $1 \mathrm{mg} \mathrm{ml}^{-1}$ (Fig. 2).

\section{${ }^{1} \mathrm{H}$ NMR quantification of hymenidin and debromo-carteramine A}

The natural volumetric concentrations of the 2 compounds in the $n$-butanol partition were found to be 


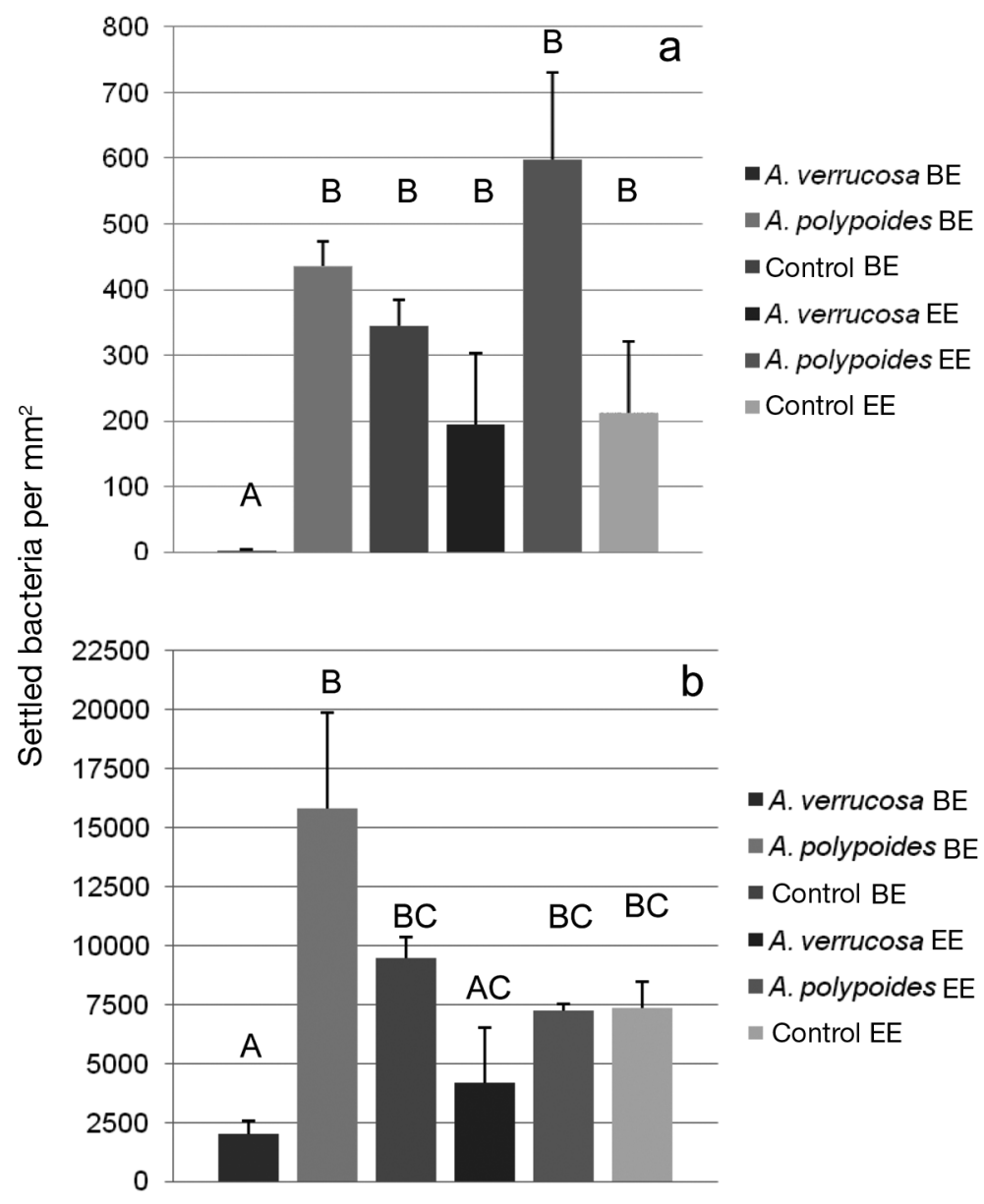

Fig. 1. Axinella polypoides and A. verrucosa. Extract partition effects on bacterial settlement. Settled bacteria were scored per $\mathrm{mm}^{2}$. Extract partitions were tested at natural volumetric concentrations. (a) Colony-forming unit (CFU) scoring method, (b) DAPI method. BE: $n$-butanol extract partition, EE: $\mathrm{Et}_{2} \mathrm{O}$ extract partition. Values are means $+\mathrm{SE}$, 3 replicates per treatment. Letters indicate significance groups from the Tukey's post hoc test following 1-way ANOVA of the log-transformed data

almost identical in Axinella verrucosa sponges from Nisida, collected in this study, and from Massa Lubrense (both Gulf of Naples), collected previously and used for the compound isolation (Haber et al. 2010). Hymenidin was present at concentrations of $3.8 \mathrm{mg} \mathrm{ml}^{-1}$ sponge volume, which is above the active concentration in the feeding deterrence assay and about 2 orders of magnitudes higher than the determined minimal inhibitory concentrations. Another previously isolated antibacterial active compound, debromo-carteramine $\mathrm{A}$, was present at whole tissue level concentrations of 1.0 and $0.9 \mathrm{mg} \mathrm{ml}^{-1}$ in the $n$-butanol partitions of $A$. verrucosa from Nisida and Massa Lubrense, respectively, which is well above the active concentrations tested by Haber et al. (2010) against an environmental bacterium.

\section{DISCUSSION}

In this study, we analyzed the chemical defenses of the 2 sympatric Mediterranean sponges Axinella polypoides and A. verrucosa against microbial fouling and in feeding deterrence of a potential predator. In other sponges of the genus Axinella and the related genus Agelas, these activities are frequently mediated by pyrrole-imidazoles, a metabolite class thus far isolated only from marine sponges (Forte et al. 2009) including $A$. verrucosa (Cimino et al. 1975, Aiello et al. 2006, Haber et al. 2010), but apparently absent in A. polypoides (Cimino et al. 1975). Our results indicate that this chemical difference relates to distinct defensive strategies against microbial fouling and predator deterrence in these 2 sponges.

Anti-microbial fouling activity was not detected in the extract partitions from Axinella polypoides. In contrast, $A$. verrucosa showed antimicrobial fouling activity, especially in its $n$-butanol partition, which inhibited bacterial settlement in the field at natural volumetric concentrations and also the growth of all tested Gram-positive bacteria as well as the Gram-negative E. coli in laboratory assays, with minimal inhibitory concentrations 2 to 3 orders of magnitude lower than its natural volumetric concentration. Mild antibacterial activity has been previously reported from extracts of both sponge species collected from the French Mediterranean coast (Amade et al. 1987) and from $A$. polypoides collected from the Atlantic coast of Morocco (El-Amraouia et al. 2010). However, only Amade et al. (1987) included marine bacteria in their test panel. The 10 marine bacteria of their panel were Gram-negative, and 9 belonged to the class of $\gamma$-Proteobacteria. The ethanol extract of $A$. verrucosa inhibited 5 of the 10 marine bacteria, while the ethanol extract of A. polypoides inhibited 4 . We did not detect activity against marine Gram-negative bacteria in our study, but the different bacterial strains and extraction methods make a direct comparison of the results difficult (e.g. the activity observed by Amade et al. 1987 could be due to very polar compounds, which could have been missed by our extraction method). Nonetheless, most marine bacteria were not inhibited by the ethanol extract of $A$. polypoides, and our results from field and laboratory assays did not indicate the presence of a chemical defense against microbial fouling in this 


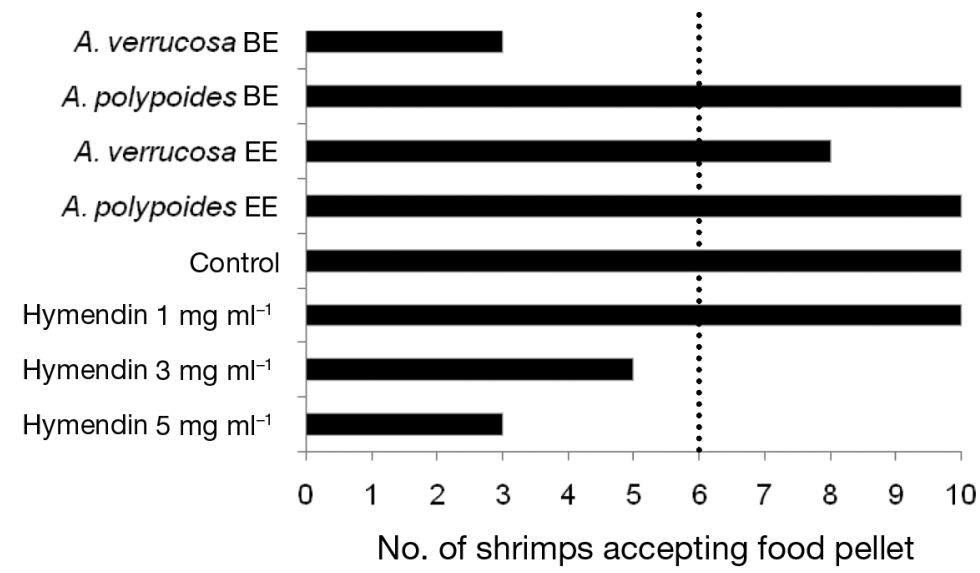

Fig. 2. Axinella polypoides and A. verrucosa. Feeding deterrence of Axinella spp. and hymenidin against the shrimp Palaemon elegans. An extract partition was considered significantly deterrent if $\leq 6$ shrimps accepted the offered food as compared to all 10 control shrimps, which all ate it, as indicated by the dotted line (Fisher's exact test, $\mathrm{p}<0.05$ ). Extract partitions were tested at natural volumetric concentrations. BE: $n$-butanol extract partition; EE: $\mathrm{Et}_{2} \mathrm{O}$ extract partition

sponge species. Bacterial fouling can also be prevented by physical defense mechanisms such as the production of mucus, tissue sloughing as described e.g. in Halichondria panicea (Barthel \& Wolfrath 1989), and by controlling the species composition of the epibiotic bacterial community. Regarding the latter possibility, the isolation of bacteria producing anti-bacterially active compounds from $A$. polypoides is noteworthy (Muscholl-Silberhorn et al. 2008). A. polypoides was the sponge species in the study with the second most antibacterial active isolates, with $54 \%$ of its isolates inhibiting at least 1 of the 3 test bacteria.

The sympatric Axinella verrucosa clearly has a chemical defense against microbial fouling, which, as in many other species of the genera Axinella and Agelas, is mediated by bromopyrrole compounds. One major constituent of the $n$-butanol partition of the $A$. verrucosa extract was the bromopyrrole hymenidin. The minimal inhibitory concentrations of this pure compound against the bacteria inhibited by the $n$ butanol partition were the same or higher than those of the $n$-butanol partition and well below the natural volumetric concentration in the sponge. This suggests that hymenidin plays a role in the sponge antibacterial defense in nature, but is not the sole compound responsible for the antibacterial activity. This is supported by the ${ }^{1} \mathrm{H}$ NMR quantification of the antibacterial active compound debromo-carteramine A, previously isolated from A. verrucosa (Haber et al. 2010), which is present in supposedly effective natural volumetric concentrations, and by the previous isolation of the mild antibacterial active bromopyrrole stevensine from $A$. verrucosa samples collected from the Bay of
Calvi, Corsica (Newbold et al. 1999, Aiello et al. 2006). In addition, bacterial settlement of the Gram-negative bacterium Vibrio harveyi has been shown to be prevented in a nontoxic mechanism by several bromopyrrole compounds that are structurally related to hymenidin (Kelly et al. 2003), e.g. oroidin, the 2-bromo-derivative of hymenidin, which was also isolated from $A$. verrucosa (Cimino et al. 1975). In the same study, Kelly et al. (2003) showed additive or synergistic effects when different bromopyrroles were tested together, which could explain the remarkable bromopyrrole diversity found in A. verrucosa (Aiello et al. 2006).

The 2 studied sponge species also differed in their chemical defense towards a potential predator. The $n$-butanol partition of Axinella verrucosa was the only partition that significantly deterred the shrimp Palaemon elegans from feeding at natural volumetric concentration. The activity was mediated by hymenidin, which significantly deterred feeding, starting at $3 \mathrm{mg} \mathrm{ml}^{-1}$, which is below its natural volumetric concentrations and is the same concentration at which hymenidin started inhibiting feeding of the Caribbean wrasse Thalassoma bifasciatum (Assmann et al. 2001a). The other structurally related bromopyrroles, stevensine and oroidin, found in A. verrucosa (Cimino et al. 1975, Aiello et al. 2006) and previously isolated from several Caribbean sponges of the genera Agelas and Axinella, have also been shown to inhibit feeding by this generalist predator (Chanas et al. 1997, Wilson et al. 1999, Assmann et al. 2001a). The feeding deterrence of a compound is largely dependent on the predator, and several examples exist in which extracts deterred 1 type but not another (see Sokolover \& Ilan 2007 and references therein). Our results for hymenidin, using a predator from a phylum not examined so far for this compound, therefore strengthen the notion of a general feeding deterrent role for hymenidin. A possible common mode of action for hymenidin in feeding deterrence of predators might involve the calcium cell homeostasis as suggested by Bickmeyer et al. (2004). Hymenidin and structurally related compounds have been located in spherulous cells, which in sponges of the genus Agelas accumulate at the ectosome (Richelle-Maurer et al. 2003). Spherulous cells have also been observed in $A$. verrucosa, where they are regularly present throughout the tissue (Steffens 2003). Accumulation of compounds on the sponge surface increases the concentration experienced by predators and microbial foulers and thus the natural volumetric concentrations underestimate the experienced concentrations. We can therefore assume multi- 
ple defensive roles for hymenidin in A. verrucosa, as described earlier for other compounds isolated from sponges including bromopyrroles (Kubanek et al. 2002, Richelle-Maurer et al. 2003).

Unlike other sympatric Mediterranean axinellids (e.g. Acanthella acuta, Axinella verrucosa, Axinella damicornis, Axinella sp.), which have been shown to chemically deter feeding by sympatric predators (Becerro et al. 2003, Sokolover \& Ilan 2007, present study), neither our own results using a crustacean predator nor a previous study using the Mediterranean wrasse Thalassoma pavo and the gastropod Strombus persicus from the coast of Israel (Sokolover \& Ilan 2007), found feeding deterrent activity in the extracts of $A$. polypoides. It is noteworthy that the extraction method used by Sokolover \& Ilan (2007) included the water phase in the extract. It is thus unlikely that potential feeding deterrent compounds would have been missed, although the possibility of inactivation or degradation (e.g. by the solvents) exists. Sokolover \& Ilan (2007) suggested the possibility of physical defense against predators by means of spicules. A. polypoides has 3 spicule types: the 2 dominant ones, both megascleres, are styles and oxea with an average size of 345 and $324 \mu \mathrm{m}$, respectively (data from Alvarez \& Hooper 2002). They are thus longer than the $250 \mu \mathrm{m}$ deemed to be sufficient for feeding deterrence based on a study of the generalist Red Sea wrasse T. klunzingeri (Burns \& Ilan 2003). In the latter study, Burns \& Ilan (2003) found 2 exceptions to the general rule: the Red Sea sponge Axinella carteri and a Caribbean Stylissa species, both belonging to the family Axinellidae. These 2 species are known to contain bromopyrrole compounds including feeding-deterrent ones (Fedoreyev et al. 1986, Assmann et al. 2001b, Assmann \& Köck 2002, Ortlepp et al. 2007), and thus might rely on chemical anti-predator defense alone. Ferguson \& Davis (2008) indicated the possibility that spicules of a size smaller than $100 \mu \mathrm{m}$ deter the generalist sea urchin Centrostephanus rodgersii. The third spicule type of A. polypoides, the microscleres of the trichodragmata type, is shorter than $30 \mu \mathrm{m}$. These spicules are not very abundant and difficult to detect in the tissue of A. polypoides (Alvarez \& Hooper 2002), which might prevent their effectiveness. However, they are generally located near the surface (which can elevate their ability to deter a predator), and no correlation between spicule density and deterrence was found by Ferguson \& Davis (2008). Clearly, further experiments are necessary to establish whether A. polypoides has a physical defense against predators.

The co-occurrence of anti-predator chemically defended and undefended sponge species on exposed reef parts has been reported from the Caribbean (Pawlik et al. 1995). Different energy allocation strategies are thought to mediate such co-existence. Chemicallyundefended species may be able to invest more in processes such as growth, wound-healing, and possibly reproduction, while tolerating partial predation as a cost of being only marginally defended (e.g. by means of physical defense). Chemically-defended species, on the other hand, invest in energetically costly defensive secondary metabolites and pay the price of lower growth rates, slower wound-healing, and less reproductive output (Walters \& Pawlik 2005, Pawlik et al. 2008, Leong \& Pawlik 2010). The 2 sympatric Mediterranean sponge species studied here clearly differed in their chemical defense against predators and possibly also against microbial fouling. Support for the theory of different energetic allocation towards growth and wound-healing comes from an enzyme activity study by Basile et al. (2009), who analyzed the ADP-ribosyl cyclase activity in different sponge species. This activity was positively correlated with growth and posttraumatic wound-healing. The 'undefended' Axinella polypoides showed high activity levels, while the 'defended' A. verrucosa and several other sponges like A. damicornis, Crambe crambe, Ircinia oros and I. variabilis that were previously either shown to chemically deter predators or known to possess feeding deterrent compounds (e.g. oroidin in Agelas oroides), showed low activity levels. Further experiments are needed to determine whether a trade-off between chemical defense and growth, wound-healing, and reproductive investment also exists in the sponges from temperate seas, where growth and reproduction can be seasonal and energy investment might therefore vary throughout the year. Other aspects of interest are the potential cost of physical defense, if such exists in A. polypoides, and how life-stage-dependent predator defense as shown for example for the Mediterranean sponges C. crambe and Dysidea avara by Uriz et al. (1996), fits into the trade-off model between growth, reproduction, and defense (Wulff 2006).

In conclusion, 2 different defensive strategies for the 2 examined co-occurring sponge species have become apparent in the present study. As hypothesized, Axinella verrucosa has chemical defenses mediated by its bromopyrrole compounds, such as hymenidin, which exhibits multiple defensive roles. The sympatric species A. polypoides, in contrast, which lacks this type of compound, also lacks such chemical defenses. These findings confirm the multiple defensive functions previously found in bromopyrroles isolated from Caribbean sponges. The Mediterranean sponges tested with a sympatric predator and sympatric microbes thus indicate that the role of these bromopyrrole compounds does not change among different ecosystems. This is in line with the notion that sponges from tropical and temperate regions have comparable feeding 
deterrence activity (Becerro et al. 2003). A recent phylogenetic study grouped $A$. verrucosa in a monophyletic clade of pyrrole-producing sponges (Gazave et al. 2010), and all included taxa were defended by these compounds against predation. This pattern raises the possibility that the multiple defensive functions of bromopyrroles in feeding deterrence, microbial antifouling, and competition for space are evolutionarily conserved. The defense mechanism of A. polypoides, however, needs further study. Chemical defense, at least against predators, has not been supported so far in this species (Sokolover \& Ilan 2007, present study), and anti-microbial fouling defense in nature remains questionable. A. polypoides has been grouped in the recent phylogeny with several Axinella spp. (Gazave et al. 2010), none of which have been shown to chemically deter predation. It would thus be interesting to examine whether these sponges also allocate more energy towards growth and woundhealing, as indicated by the high levels of activity in the ADP-ribosyl cyclase in A. polypoides (Basile et al. 2009), thus supporting an evolutionarily conserved alternative strategy to investment in secondary metabolites.

Acknowledgements. We thank G. Villani and F. Castelluccio (ICB-CNR Pozzuoli, Italy) for technical assistance. The staff of the zoological station 'Anton Dohrn', Naples, Italy, is acknowledged for help in microscopic analysis. The NMR spectra were recorded at the ICB NMR Facility, the staff of which is gratefully acknowledged. The study was financially supported through an EU RTN Marie-Curie grant (339 FP6, BIOCAPITAL, contract no. MRTN-CT- 2004-512301).

\section{LITERATURE CITED}

Aiello A, D'Esposito M, Fattorusso E, Menna M, Müller WEG, Peroviç-Ottstadt S, Schröder HC (2006) Novel bioactive bromopyrrole alkaloids from the Mediterranean sponge Axinella verrucosa. Bioorg Med Chem 14:17-24

Altschul SF, Gish W, Miller W, Myers EW, Lipman DJ (1990) Basic local alignment search tool. J Mol Biol 215: 403-410

Alvarez B, Hooper JNA (2002) The family Axinellidae Carter, 1875. In: Hooper JNA, Van Soest RWM (eds) Systema Porifera: a guide to the classification of sponges, Vol 1. Kluwer Academic/Plenum Publisher, New York, NY, p 724-747

Amade P, Chrroin C, Baby C, Vacelet J (1987) Antimicrobial activities of marine sponges from the Mediterranean Sea. Mar Biol 94:271-275

Assmann M, Köck M (2002) Monobromoisophakellin, a new bromopyrrole alkaloid from the Caribbean sponge Agelas sp. Z Naturforsch C 57:153-156

Assmann M, Zea S, Köck M (2001a) Sventrin, a new bromopyrrole alkaloid from the Caribbean sponge Agelas sventres. J Nat Prod 64:1593-1595

> Assmann M, Van Soest RWM, Köck M (2001b) New antifeedant bromopyrrole alkaloid from the Caribbean sponge Stylissa caribica. J Nat Prod 64:1345-1347

Barthel D, Wolfrath B (1989) Tissue sloughing in the sponge Halichondria panicea: a fouling organism prevents being fouled. Oecologia 78:357-360

Basile G, Cerrano C, Radjasa O, Povera P, Zocchi E (2009) ADP-ribosyl cyclase and abscisic acid are involved in seasonal growth and in post-traumatic tissue regeneration of Mediterranean sponges. J Exp Mar Biol Ecol 381:10-17

Becerro MA, Thacker RW, Turon X, Uriz MJ, Paul VJ (2003) Biogeography of sponge chemical ecology: comparison of tropical and temperate defenses. Oecologia 135:91-101

Bickmeyer U, Drechsler C, Köck M, Assmann M (2004) Brominated pyrrole alkaloids from marine Agelas sponges reduce depolarization-induced cellular calcium elevation. Toxicon 44:45-51

Blunt JW, Copp BR, Hu WP, Munro MHG, Northcote PT, Prinsep MR (2009) Marine natural products. Nat Prod Rep 26:170-244

> Braekman JC, Daloze D, Stoller C, Van Soest RWM (1992) Chemotaxonomy of Agelas (Porifera: Demospongiae). Biochem Syst Ecol 20:417-431

Burns E, Ilan M (2003) Comparison of anti-predatory defenses of Red Sea and Caribbean sponges: 2. Physical defense. Mar Ecol Prog Ser 252:115-123

Burns E, Ifrach I, Carmeli S, Pawlik JR, Ilan M (2003) Comparison of anti-predatory defenses of Red Sea and Caribbean sponges. 1. Chemical defense. Mar Ecol Prog Ser 252: 105-114

Chanas B, Pawlik JR, Lindel T, Fenical W (1997) Chemical defense of the Caribbean sponge Agelas clathrodes (Schmidt). J Exp Mar Biol Ecol 208:185-196

Cimino G, De Stefano S, Minale L, Sodano G (1975) Metabolism in Porifera. III. Chemical patterns and the classification of the Demospongiae. Comp Biochem Physiol 50B: 279-285

De Goeij JM, De Kluijver A, Van Duyl FC, Vacelet J and others (2009) Cell kinetics of the marine sponge Halisarca caerulea reveal rapid cell turnover and shedding. J Exp Biol 212: 3892-3900

Dobretsov S, Dahms H, Qian P (2005a) Antibacterial and antidiatom activity of Hong Kong sponges. Aquat Microb Ecol 38:191-201

> Dobretsov S, Dahms H, Tsoi MY, Qian P (2005b) Chemical control of epibiosis by Hong Kong sponges: the effect of sponge extracts on micro- and macrofouling communities. Mar Ecol Prog Ser 297:119-129

El-Amraouia B, Biard JF, Uriz MJ, Rifai S, Fassouane A (2010) Antifungal and antibacterial activity of Porifera extracts from the Moroccan Atlantic coast. J Mycol Med 20:70-74

Engel S, Pawlik JR (2000) Allelopathic activities of sponge extracts. Mar Ecol Prog Ser 207:273-281

Fedoreyev SA, Utkina NK, Ilyin SG, Reshetnyak MV, Maximov OB (1986) The structure of dibromoisophakellin from the marine sponge Acanthella carteri. Tetrahedron Lett $27: 3177-3180$

Ferguson AM, Davis AR (2008) Heart of glass: spicule armament and physical defense in temperate reef sponges. Mar Ecol Prog Ser 372:77-86

> Fontana A, Antoniazzi F, Cimino G, Mazza G, Trivellone E, Zanone B (1992) High-resolution NMR detection of cholesterol oxides in spray-dried egg yolk. J Food Sci 57: 869-872

Forte B, Malgesini B, Piutti C, Quartieri F, Scolaro A, Papea G (2009) A submarine journey: the pyrrole-imidazole alkaloids. Mar Drugs 7:705-753

Furrow FB, Amsler CD, McClintock JB, Baker BJ (2003) Surface sequestration of chemical feeding deterrents in the Antarctic sponge Latrunculia apicalis as an optimal defense against sea star spongivory. Mar Biol 143:443-449 Gazave E, Carteron S, Chenuil A, Richelle-Maurer E, Boury- 
Esnault N, Borchiellini C (2010) Polyphyly of the genus Axinella and of the family Axinellidae (Porifera: Demospongiae). Mol Phylogenet Evol 57:35-47

Haber M, Carbone M, Ilan M, Gavagnin M (2010) Structure of debromo-carteramine A, a novel alkaloid from the Mediterranean sponge Axinella verrucosa. Arkivoc ii:233-239

- Harder T, Lau SCK, Tam W, Qian PY (2004) A bacterial culture-independent method to investigate chemically mediated control of bacterial epibiosis in marine invertebrates by using TRFLP analysis and natural bacterial populations. FEMS Microbiol Ecol 47:93-99

$>$ Henrikson AA, Pawlik JR (1995) A new antifouling assay method: results from field experiments using extracts of four marine organisms. J Exp Mar Biol Ecol 194:157-165

Hill MS, Lopez NA, Young KA (2005) Anti-predator defenses in western North Atlantic sponges with evidence of enhanced defense through interactions between spicules and chemicals. Mar Ecol Prog Ser 291:93-102

Janas U, Zarzycki T, Kozik P (2004) Palaemon elegans-a new component of the Gulf of Gdańsk macrofauna. Oceanologia 46:143-146

> Jones AC, Blum JE, Pawlik JR (2005) Testing for defensive synergy in Caribbean sponges: bad taste or glass spicules? J Exp Mar Biol Ecol 322:67-81

Kelly SR, Jensen PR, Henkel TP, Fenical W, Pawlik JR (2003) Effects of Caribbean sponge extracts on bacterial attachment. Aquat Microb Ecol 31:175-182

Kelman D, Kashman Y, Rosenberg E, Ilan M, Ifrach I, Loya Y (2001) Antimicrobial activity of the reef sponge Amphimedon viridis from the Red Sea: evidence for selective toxicity. Aquat Microb Ecol 24:9-16

Kubanek J, Whalen KE, Engel S, Kelly SR, Henkel TP, Fenical W, Pawlik JR (2002) Multiple defensive roles for triterpene glycosides from two Caribbean sponges. Oecologia 131: 125-136

Lau SCK, Thiyagarajan V, Cheung SCK, Qian PY (2005) Roles of bacterial community composition in biofilms as a mediator for larval settlement of three marine invertebrates. Aquat Microb Ecol 38:41-51

Lee OO, Yang LH, Li X, Pawlik JR, Qian PY (2007) Surface bacterial community, fatty acid profile, and antifouling activity of two congeneric sponges from Hong Kong and the Bahamas. Mar Ecol Prog Ser 339:25-40

Leong W, Pawlik JR (2010) Evidence of a resource trade-off between growth and chemical defenses among Caribbean coral reef sponges. Mar Ecol Prog Ser 406:71-78

Mayer AMS, Hamann TM (2005) Marine pharmacology in 2001-2002: marine compounds with anthelmintic, antibacterial, anticoagulant, antidiabetic, antifungal, antiinflammatory, antimalarial, antiplatelet, antiprotozoal, antituberculosis, and antiviral activities; affecting the cardiovascular, immune and nervous systems and other miscellaneous mechanisms of action. Comp Biochem Physiol 140C:265-286

Mollo E, Gavagnin M, Carbone M, Castelluccio F and others (2008) Factors promoting marine invasion: a chemoecological approach. Proc Natl Acad Sci USA 105: 4582-4586

Muscholl-Silberhorn A, Thiel V, Imhoff JF (2008) Abundance and bioactivity of cultured sponge-associated bacteria from the Mediterranean Sea. Microb Ecol 55:94-106

> Newbold RW, Jensen PR, Fenical W, Pawlik JR (1999) Anti-

Editorial responsibility: Joseph Pawlik,

Wilmington, North Carolina, USA microbial activity of Caribbean sponge extracts. Aquat Microb Ecol 19:279-284

> Ortlepp S, Sjörgren M, Dahlström M, Weber H and others (2007) Antifouling activity of bromotyrosine-derived sponge metabolites and synthetic analogues. Mar Biotechnol 9:776-785

Pawlik JR (1993) Marine invertebrate chemical defenses. Chem Rev 93:1911-1922

Pawlik JR, Chanas B, Toonen RJ, Fenical W (1995) Defenses of Caribbean sponges against predatory reef fish. 1. Chemical deterrence. Mar Ecol Prog Ser 127:183-194

Pawlik JR, Steindler L, Henkel TP, Beer S, Ilan M (2007a) Chemical warfare on coral reefs: sponge metabolites differentially affect coral symbiosis in situ. Limnol Oceanogr 52:907-911

Pawlik JR, McMurray SE, Henkel TP (2007b) Abiotic factors control sponge ecology in Florida mangroves. Mar Ecol Prog Ser 339:93-98

Pawlik JR, Henkel TP, McMurray SE, López-Legentil S, Loh TL, Rohde S (2008) Patterns of sponge recruitment and growth on a shipwreck corroborate chemical defense resource trade-off. Mar Ecol Prog Ser 368:137-143

> Qian PY, Xu Y, Fusetani N (2010) Natural products as antifouling compounds: recent progress and future perspectives. Biofouling 26:223-234

Richelle-Maurer E, De Kluiyver MJ, Feio S, Gaudêncio S and others (2003) Localization and ecological significance of oroidin and sceptrin in the Caribbean sponge Agelas conifera. Biochem Syst Ecol 31:1073-1091

> Sjögren M, Göransson U, Johnson AL, Dahlström M and others (2004) Antifouling activity of brominated cyclopeptides from the marine sponge Geodia barretti. J Nat Prod 67:368-372

Sokolover N, Ilan M (2007) Assessing anti-predatory chemical defences among ten eastern Mediterranean sponges. J Mar Biol Assoc UK 87:1785-1790

Steffens S (2003) Prokaryoten und mikrobielle Eukaryoten aus marinen Schwämmen (Prokaryotes and microbial eukaryotes from marine sponges). PhD thesis, Rheinische Friedrich-Wilhelm-Universität, Bonn

Tsoukatou M, Hellio C, Vaigas C, Harvala C, Roussis V (2002) Chemical defense and antifouling activity of three Mediterranean sponge of the genus Ircinia. Z Naturforsch C 57:161-171

> Uriz MJ, Turon X, Becerro MA, Galera J (1996) Feeding deterrence in sponges. The role of toxicity, physical defenses, energetic contents, and life-history stage. J Exp Mar Biol Ecol 205:187-204

Wahl M (1989) Marine epibiosis. I. Fouling and antifouling: some basic aspects. Mar Ecol Prog Ser 58:175-189

Walters KD, Pawlik JR (2005) Is there a trade-off between wound-healing and chemical defenses among Caribbean reef sponges? Integr Comp Biol 45:352-358

> Wilson DM, Puyana M, Fenical W, Pawlik JR (1999) Chemical defense of the Caribbean reef sponge Axinella corrugata against predatory fishes. J Chem Ecol 25:2811-2823

> Wright JT, Benkendorff K, Davis AR (1997) Habitat associated differences in temperate sponge assemblages: the importance of chemical defence. J Exp Mar Biol Ecol 213: 199-213

> Wulff JL (2006) Ecological interactions of marine sponges. Can J Zool 84:146-166

Submitted: September 16, 2010; Accepted: November 5, 2010 Proofs received from author(s): January 13, 2011 